\title{
Pengaruh Perbedaan Gaya Belajar dan Keikutsertaan Organisasi Terhadap Pemahaman Hasil Pembelajaran Mahasiswa
}

\author{
Nia Savira Febrianti \\ Pendidikan IPA, Jurusan Pendidikan MIPA, FKIP, Universitas Jember, Indonesia \\ Email: nsavira09@gmail.com
}

\begin{abstract}
This article is made based on the diversity of different learning styles and student interest in talent, especially participation in organizational activities. This article was made with the aim to find out the different learning styles for each student and the participation of organizational activities and their influence in gaining understanding and learning outcomes. The differences in learning styles and talent interests of each student are abilities in themselves. Teachers can also play a role in helping understanding learning in each individual who has different learning styles and interests. In this article it can be seen that organizational activities have positive and negative influences in learning and learning outcomes. The writing of this article uses the literature study method, by looking at various sources or references, such as books or several other journals concerning the same material as the article I made. With this article, it can be taken as a reference in learning. Thus, learning goals can be achieved without having to put pressure on students.
\end{abstract}

Kata Kunci: learning style, interest in talent, organizational activities, understanding of learning

\section{PENDAHULUAN}

Salah satu wadah proses sumber daya manusia yang berkualitas adalah melalui lembaga pendidikan, dalam hal ini adalah perguruan tinggi atau universitas. Pendidikan adalah usaha sadar dan terencana untuk mewujudkan suasana belajar dan proses pembelajaran agar peserta didik secara aktif mengembangkan potensi dirinya untuk memiliki kepribadian, kecerdasan, serta keterampilan yang diperlukan dirinya, keluarga, masyarakat, bangsa dan negara. Kegiatan belajar mengajar di kampus merupakan kegiatan yang harus didukung, baik dari media pembelajaran, tempat, dosen, maupun mahasiswa. Oleh karena itu, selain kampus menyediakan fasilitas yang lengkap bagi mahasiswa, mahasiswapun harus dikondisikan secara baik agar pembelajaran dapat efektif. Keberhasilan dalam proses pembelajaran dapat dilihat pada prestasi belajar mahasiswa itu sendiri. Prestasi belajar selalu dihubungkan dengan hasil belajar seorang mahasiswa. Mahasiswa yang prestasi belajarnya tinggi dapat dikatakan bahwa ia telah berhasil dalam belajar. Prestasi belajar merupakan perpaduan antara kemampuan, minat, bakat, kebiasaan belajar, motivasi, serta lingkungan belajar yang saling berhubungan dan mempengaruhi pola perilaku setiap mahasiswa (Pratiwi,2016).

Peserta didik merupakan suatu organisme yang sedang tumbuh dan berkembang. Setiap dari peserta didik memiliki potensi masing-masing seperti bakat, minat, kebutuhan dan lain-lain. Dalam era modern ini di bidang pendidikan, perbedaan karakteristik peserta didik perlu dipertimbangkan dan diperhatikan dalam kegiatan belajar mengajar. Maka dari itu, setiap pelaksanaan kegiatan belajar mengajar di sekolah harus sesuai dengan karakteristik, gaya belajar dan kecerdasan masing-masing peserta didik. Dengan demikian, karakteristik gaya belajar, kecerdasan peserta didik merupakan hal yang perlu diketahui pendidik yang secara langsung mendidik peserta didik tersebut. Bagi sesama peserta didik juga perlu diketahui agar dapat bertoleransi dengan sesama peserta didik yang memiliki perbedaan karakteristik. Guru dapat memberikan contoh sikap penerimaan dan toleransi sehingga peserta didik merasa nyaman di sekolah sekaligus untuk menanamkan nilai-nilai dan bahkan menikmati perbedaan diantara mereka tanpa adanya rasa curiga (Hermawan,2016). 
Sudah menjadi keyakinan semua orang bahwa masing-masing individu memiliki karakteristik, minat bakat, dan kemampuan yang berbeda-beda. Ada yang berkemampuan cepat, sedang, dan ada yang berkemampuan rendah. Menurut tinjauan psikologis setiap anak memiliki perbedaan dengan lainnya. Bakat adalah kemampuan bawaan yang merupakan potensi yang masih perlu dikembangkan atau dilatih untuk mencapai suatu kecakapan, pengetahuan, dan keterampilan. Minat adalah kecenderungan yang tetap untuk memperhatikan dan mengenang beberapa kegiatan. Kegiatan yang diminati seseorang, diperhatikan terus-menerus yang disertai dengan rasa senang. Jika perhatian sifatnya sementara dan belum tentu diikuti perasaan senang, sedangkan minat selalu diikuti dengan perasaan senang dan dari situ diperoleh kepuasaan. Mahasiswa menjadi pusat dari kegiatan pembelajaran. Oleh karena itu, pendidik dalam mengambil segala keputusan atau tindakan harus mempertimbangkan kondisi dan karakteristik mahasiswa yang akan dibelajarkan. Kondisi dan karakteristik mahasiswa menurut Wina Sanjaya (2011:169) merupakan salah satu pertimbangan yang harus diperhatikan, baik menyangkut minat dan bakat mahasiswa. Salah satu karakteristik mahasiswa yang harus dipertimbangkan dalam menciptakan pembelajaran agar dapat mencapai prestasi tinggi yaitu kecenderungan gaya belajar yang dimiliki mahasiswa itu sendiri (Hadi,2017).

Gaya belajar merupakan cara termudah bagi seseorang untuk menyerap, memahami dan mengelola suatu informasi. Seringkali masalah gaya belajar menjadi salah satu penyebab permasalahan mahasiswa dalam belajar. Kesesuaian gaya mengajar guru dengan gaya belajar menjadi aspek penting dalam menciptakan dan melaksanakan pembelajaran. Kesesuaian ini berpengaruh terhadap prestasi belajar mahasiswa. Mencocokkan gaya belajar mahasiswa dengan gaya mengajar yang tepat akan menghasilkan interaksi yang sukses antara guru dan mahasiswa serta hasil belajarnya pun akan membaik. Ketika guru mampu menciptakan pembelajaran yang sesuai dengan kecenderungan gaya belajar mahasiswa, maka mahasiswa akan mudah dalam mengolah informasi sehingga pada akhirnya dapat mencapai prestasi belajar tinggi (Gunawan,2005:15).

Organisasi adalah suatu sarana dan wahana untuk mengembangkan bakat, minat, serta potensi diri bagi para aktivis yang ada dalam organisasi tersebut. Organisasi kemahasiswaan merupakan bentuk kegiatan di perguruan tinggi yang diselenggarakan dengan prinsip, dari, oleh, dan untuk mahasiswa. Organisasi kemahasiswaan juga sebagai wadah dan sarana pengembangan kegiatan ekstrakurikuler mahasiswa di perguruan tinggi yang meliputi pengembangan penalaran, keilmuwan, minat, bakat, dan kegemaran mahasiswa itu sendiri. Perbedaan pandangan antara mahasiswa tentang organisasi menarik perhatian untuk mencari tahu apakah benar organisasi berpengaruh buruk terhadap prestasi belajar mahasiswa atau malah sebaliknya organisasi membawa dampak baik terhadap prestasi belajar mahasiswa. Di balik semua manfaat positif yang bisa didapatkan oleh mahasiswa guna mempersiapkan diri menjadi seorang intelektual muda, kegiatan kuliah sambil mengikuti kegiatan organisasi merupakan hal yang sulit dilakukan. Mahasiswa harus membagi waktu dan konsentrasinya menjadi dua serta bertanggung jawab terhadap komitmen dari kedua aktivitas tersebut. Dalam menjaga komitmen tersebut dibutuhkan motivasi yang tinggi, dengan adanya motivasi belajar akan mengarahkan mahasiswa untuk lebih rajin belajar dan mengarahkan mahasiswa untuk mencapai tujuannya, misalnya dengan mengatur atau me-manage waktu agar dapat menyelesaikan kuliah tepat waktu. (Purwanto, 2004: 72)

Segala aktivitas yang dilakukan seseorang pasti memiliki dampak atau pengaruh yang ditimbulkan dari kegiatannya, begitu pula dengan kegiatan organisasi. Kegiatan organisasi memiliki pengaruh terhadap seseorang yang mengikuti organisasi tersebut, baik pengaruh positif maupun pengaruh negatif. Pengaruh terhadap tingkah laku, kedisiplinan, pola berfikir, tata kelakukan, dan tindakan maupun pengaruh pada prestasi pengurus 
tersebut dalam belajar. Pengaruh dalam jangka waktu yang dekat biasanya yang ditimbulkan adalah perubahan sikap, tingkah laku serta kepribadian yang mendorong pengurus bersifat dewasa dalam menghadapi setiap tantangan dalam menjalankan aktivitas organisasi yang dilaksanakan. Dalam jangka waktu yang lama diketahui hasilnya adalah proses belajar yang berdampak terhadap indeks prestasi yang dibuat oleh pengurus organisasi tersebut (Pradayu, 2017).

Perbedaan pandangan antara mahasiswa tentang organisasi menarik perhatian peneliti untuk meneliti apakah benar organisasi menarik berpengaruh buruk terhadap prestasi belajar mahasiswa atau malah sebaliknya organisasi membawa dampak baik terhadap hasil belajar mahasiswa.

\section{METODE PENELITIAN}

Data-data yang dipergunakan dalam penyusunan artikel ilmiah ini berasal dari berbagai literature kepustakaan yang berkaitan dengan permasalahan yang dibahas, dan juga wawancara kepada beberapa mahasiswa yang bersangkutan dengan topik yang akan dibahas. Beberapa jenis referensi utama yang digunakan adalah buku tentang pembelajaran dan gaya belajar, dan jurnal ilmiah. Jenis data yang diperoleh bersifat kualitatif. Informasi didapatkan dari hasil wawancara dan berbagai literatur dan disusun berdasarkan hasil studi dari informasi yang diperoleh.

Penulisan diupayakan saling terkait antar satu sama lain dan sesuai dengan topik yang dibahas. Data yang terkumpul diurutkan sesuai dengan topik kajian. Kemudian dilakukan penyusunan artikel ilmiah berdasarkan data atau referensi yang ada. Simpulan didapatkan setelah merujuk kembali pada topik yang dibahas atau pembahasan. Simpulan yang ditarik mempresentasikan pokok bahasan artikel ilmiah ini, serta didukung dengan saran praktis sebagai rekomendasi selanjutny

\section{HASIL DAN PEMBAHASAN}

Salah satu aspek yang menentukan perkembangan mahasiswa adalah memahami perbedaan invidual setiap mahasiswa. Tugas utama guru adalah mengajar dalam proses pembelajaran yang dihadapin mahasiswa dengan unik. Unik disini mengandung pengertian bahwa mahasiswa yang satu dengan yang lain pasti berbeda dan kondisi individu itu sendiri tidak menetap. Secara umum, perbedaan individual yang perlu dipertimbangkan dalam pengajaran di kelas adalah faktor yang menyangkut kesiapan mahasiswa untuk menerima pengajaran karena perbedaan tersebut akan menentukan sistem pendidikan seluruhnya. Perbedaanperbedaan tersebut harus diselesaikan dengan pendekatan kepada individualnya juga, tetapi juga disadari bahwa pendidikan tidak hanya untuk mengembangkan individu, tetapi juga bertujuan dalam kaitannya dengan pola kehidupan masyarakat yang bervariasi. Perbedaan individual banyak variasinya, antara lain kecerdasan (intelegensi) setiap anak berbeda-beda. Anak-anak yang kurang kecerdasannya umumnya belajar lebih lamban. Mereka memerlukan lebih banyak latihan dan waktu untuk maju dari tipe belajar yang satu ke tipe yang lain. Sedangkan anak-anak yang memiliki IQ tinggi biasanya mempunyai kemampuan belajar yang lebih baik, cepat, tidak terlalu memerlukan latihan, dan dapat menyelesaikan pekerjaan dalam waktu yang singkat. Selanjutnya adalah bakat, bakat sangat berpengaruh terhadap tingkat perkembangan mahasiswa. Setiap mahasiswa pasti memiliki bakat dan minat yang berbeda-beda, bakat turut menentukan perbedaan-perbedaan pada hasil belajar sikap, minat, dan lain-lain.

Universitas merupakan salah satu lembaga pendidikan yang diharapkan menjadi harapan dalam mewujudkan suatu tujuan pendidikan nasional. Universitas diharapkan mampu meningkatkan bakat serta minat mahasiswa melalui berbagai kegiatan yang berbasis peningkat kemampuan mahasiswa. Melalui berbagai kegiatan kemahasiswaan, mahasiswa diharapkan mampu meningkatkan kemampuan, baik kognitif, afektif, maupun psikomotorik. Berbagai macam upaya yang dapat ditempuh guna mengembangkan setiap potensi yang dimiliki mahasiswa salah satunya adalah dengan cara melalui 
kegiatan-kegiatan mahasiswa yang mampu meningkatkan bakat, pemikiran kritis, kreatif, dan inovatif melalui minat-minat yang dimiliki mahasiswa tersebut. Oleh sebab itu mahasiswa diberikan peluang untuk mengikuti berbagai macam kegiatan kemahasiswaan di luar kuliah atau bidak akademik dengan mengikuti unit kegiatan kemahasiswaan ataupun organisasi kemahasiswaan lain seperti himpunan mahasiswa jurusan. Salah satu alat untuk mengukur kemampuan dari setiap mahasiswa adalah dengan mengikuti kegiatan-kegiatan di dalam organisasi. Namun, masih ada satu alat ukur yang lain yang dapat digunakan untuk mengukur kompetensi dari mahasiswa tersebut adalah dengan keberhasilan menyelesaikan studi tersebut. Kegiatan kegiatan organisasi dan prestasi belajar yang baik merupakan modal yang bagus untuk membentuk kesiapan individu dalam terjun ke dunia kerja. Dalam hal ini diharapkan dengan mengikuti kegiatan organisasi mahasiswa mampu memberikan pengalaman kepada mahasiswa. Sedangkan prestasi belajar sebagai alat pengukur tingkat kematangan kemampuan kognitif mahasiswa sehingga lebih memperkuat kesiapan kerja saat terjun ke dunia kerja. Aktivitas organisasi memiliki pengaruh yang positif maupun pengaruh negatif. Pengaruh terhadap tingkah laku, kedisiplinan, pola berfikir, maupun pengaruh pada hasil dan prestasi belajar

Kegiatan organisasi menimbulkan efek terhadap setiap pelaksanaannya. Efek tersebut dapat dirasakan dalam jangka waktu yang dekat dan dalam jangka waktu yang lama. Pengaruh yang ditimbulkan dalam jangka waktu yang dekat adalah bagaimana pengurus dapat menyesuaikan waktu terhadap aktivitas yang dilakukan baik aktivitas perkuliahan maupun aktivitas organisasi. Setiap pengurus pasti berbedabeda dalam memiliki cara masing-masing dalam membagi waktu dalam menjalankan aktivitasnya. Pengaruh yang ditimbulkan oleh tidak mampunya pengurus dalam mengatur waktu juga akan berdampak didalam aktivitas belajar pengurus organisasi terganggu, maka hasil belajar yang didapat juga akan terganggu. Hasil dari wawancara peneliti dengan salah satu mahasiswa yang mengikuti kegiatan organisasi ini bagi dia, dia sudah terbiasa dengan kegiatan yang sangat padat di selasela kuliah nya. Dia mengikuti banyak kegiatan organisasi, tetapi dia tidak merasa kesulitan dalam membagi waktunya. Karena dia sudah enjoy dengan kegiatan, sehingga tidak terjadi masalah tentang hasil dalam belajarnya, dalam belajar pun dia tidak merasa kesulitan atau keteteran. Hal ini berarti ini kegiatan organisasi ini tidak menjadikan dampak negatif terhadap hasil belajarnya.

Masalah yang sering dihadapi mahasiswa yang aktif dalam kegiatan organisasi adalah kurang pandainya membagi waktu dengan baik untuk belajar, kurang tepatnya cara belajar dengan kemampuan yang dimilikinya, rendahnya tingkat intelegensi yang dapat menyebabkan daya serap mahasiswa terhadap materi pelajaran rendah, konsentrasi mahasiswa yang kurang dalam belajar akan mempengaruhi mahasiswa dalam menerima materi pelajaran, kurangnya keaktifan mahasiswa secara positif sehingga sedikit manfaat yang diperoleh dari keaktifannya berorganisasi dan rendahnya kontribusi yang diberikannya kepada organisasi. Keaktifan mahasiswa dalam mengikuti kegiatan organisasi di kampus akan menyita waktu belajar dan istirahat, apalagi banyak mahasiswa yang mengikuti lebih dari satu kegiatan organisasi, akibatnya mahasiswa tidak dapat belajar dengan baik apabila kondisi fisiknya tidak mendukung kegiatan belajarnya. Setiap manusia mempunyai kemampuan yang berbeda-beda untuk berkembang. Demikian pula mahasiswa mempunyai potensi yang berbeda, baik intelegensinya, motivasi belajar, kemauan belajar, dan sebagainya.

Menurut salah satu mahasiswa yang saya wawancarai ini, dia yang aktif dalam kegiatan organisasi mendapatkan manfaat dari kegiatan yang dikutinya, antara lain bertambahnya wawasan mahasiswa dan kemampuan untuk bersosialisasi dengan teman maupun guru yang dapat membantu dalam mengikuti proses belajar mengajar dengan baik, sehingga dapat mencapai prestasi yang tinggi. Melalui kegiatan organisasi dapat bertambah wawasan mengenai yang mungkin berhubungan 
dengan pelajaran di dalam kelas. Melalui kegiatan organisasi juga dapat menyalurkan bakat, minat, dan potensi yang dimiliki. Hasil yang dicapai mahasiswa setelah mengikuti kegiatan organisasi dan berdampak pada hasil belajar yang terdapat hubungannya dengan kegiatan tersebut akan mendapat nilai baik pada pelajaran tersebut. Dan juga mahasiswa yang aktif dalam kegiatan organisasi akan terampil dalam berorganisasi, mengelola, memecahkan masalah sesuai karakteristik organisasi yang digeluti.

Faktor keaktifan mahasiswa dalam mengikuti kegiatan organisasi ikut serta mempengaruhi prestasi belajarnya. Karena dengan melibatkan diri dalam organisasi sudah pasti konsekuensinya banyak pula kegiatan yang harus dilakukan. Banyaknya kegiatan yang harus dilakukan maka semakin berkurang waktunya untuk belajar maupun beristirahat. Tetapi dengan banyaknya kegiatan yang harus diikuti oleh mahasiswa dengan berbagai kapasitas akan membuat mahasiswa semakin luas cakrawala pikirnya. Mahasiswa akan terbiasa untuk menggunakan waktu luang yang ada dengan sebaik-baiknya, sehingga meskipun banyak mengikuti kegiatan organisasi, tidak akan terlalu memengaruhi kegiatan belajarnya, bahkan harus menjadi motivasi lebih giat belajarnya. Mahasiswa yang mengikuti kegiatan organisasi akan dapat mengambil dampak nilai-niai positif dari kegiatan yang diikutinya dan akan dapat mencapai belajar sesuai dengan yang diharapkannya. Mahasiswa yang bisa membagi waktunya dengan baik antara organisasi dengan kuliah kemungkinan besar prestasi belajarnya lebih baik dibandingkan dengan mahasiswa yang tidak bisa membagi waktunya dengan baik.

Sedangkan mahasiswa yang lain yang tidak mengikuti kegiatan organisasi, mereka juga lebih nyaman dengan pilihannya karena menurut mereka kegiatan organisasi, rapat, dan lain-lain sangat mengganggu proses belajarnya sehingga menurutnya akan berdampak buruk kepada hasil belajar. Jadi, dia ini tidak pandai dalam mengatur waktunya dan tidak berminat dalam mengikuti kegiatan-kegiatan organisasi. Maka dari itu, setiap orang pasti memiliki minat dan kemampuan yang berbeda-beda dalam proses belajar, tergantung dari diri pribadinya dalam menempatkan posisinya. Jadi, mengikuti atau tidaknya kegiatan organisasi atau mengenai dampak baik atau buruknya terhadap hasil belajar tergantung pribadi masing-masing.

Gaya belajar setiap mahasiswa juga pasti berbeda-beda. Secara umum gaya belajar dibagi menjadi tiga kategori yaitu gaya belajar visual, auditorial, dam kinestetik yang ditandai dengan ciri-ciri perilaku tertentu. Masing-masing mahasiswa sebenarnya belajar dengan menggunakan tiga gaya belajar. Namun, kebanyakan mahasiswa lebih cenderung pada salah satu diantara ketiga gaya belajar tersebut. Sebagian orang mungkin memiliki gaya belajar tertentu yang dominan digunakan dalam berbagai situasi, sehingga kurang menggunakan gaya belajar yang lain. Hal tersebut tidak menjadikan salah satu gaya belajar yang paling baik. Tidak ada gaya belajar tertentu yang lebih unggul dibandingkan yang lainnya. Semua mahasiswa tidak memproses informasi yang diterima dengan cara yang sama. Hal tersebut menunjukkan bahwa gaya belajar yang dimiliki setiap mahasiswa berbedabeda.

Dari hasil wawancara, ada anak yang suka belajar dengan cara melihat obyek secara langsung, mendengarkan penjelasan dari guru, dan ada pula yang suka belajar dengan cara mempraktikkan langsung. Ada pula mahasiswa yang suka belajar secara berkelompok, sedangkan yang lain memilih adanya guru ataupun orangtua, yang lain lagi merasa paling efektif ketika belajar sendiri. Setiap faktor yang mempengaruhi kecenderungan gaya belajar sama-sama memberikan pengaruh terhadap gaya belajar mahasiswa, misalnya gaya berpikir mahasiswa bisa diakibatkan oleh gaya mengajar guru. Namun pada saat bersamaan guru juga berusaha menyesuaikan gaya mengajar agar sesuai dengan gaya berfikir mahasiswa.

Gaya belajar termasuk salah satu faktor yang berasal dari dalam diri mahasiswa yang dapat mempengaruhi prestasi belajar. Individu memiliki keunikan masing-masing yang dapat membuatnya 
berbeda dari individu yang lain. Gaya belajar termasuk dalam keunikan tersebut. Setiap mahasiswa memiliki kecenderungan gaya belajar yang berbeda-beda. Gaya mengajar guru juga menjadi salah satu faktor yang mempengaruhi gaya belajar mahasiswa, misalnya ketika guru cenderung mengajar dengan gaya auditorial maka mahasiswa berusaha untuk menyesuaikan hal tersebut dengan cara memaksimalkan kecenderungan gaya belajar auditorial yang dimiliki. Apabila peristiwa tersebut terjadi secara terus menerus, maka kecenderungan gaya belajar mahasiswa dapat berubah karena sudah terbiasa memaksimalkan kecenderungan gaya belajar tersebut. Sehingga tingkat pemahaman belajar dan dampak dari hasil belajar tergantung pada mahasiswa itu sendiri, jika dia lebih mampu menggunakan gaya belajar yang biasa ia gunakan, maka dia juga lebih bisa mendapatkan pemahaman yang lebih baik, dan hasil belajarnya juga pasti baik. Disini guru juga berperan besar dalam memamahi setiap gaya belajar mahasiswanya yang beragam dan tidak memaksakan kehendak peserta didiknya untuk mengikuti gaya belajar yang lain, karena tingkat pemahaman setiap individu berbeda-beda.

Jadi, hasil belajar mahasiswa ini juga tergantung dari pribadi masing-masing dalam menerima pembelajaran yang menurutnya nyaman seperti apa. Jika sudah nyaman dengan kebiasaan gaya belajar pilihannya, akan membuat mahasiswa lebih mudah menerima pembelajaran sehingga akan berdampak positif dan membuat hasil belajarnya menjadi baik. Sebaliknya, apabila dia mengikuti gaya belajar orang lain yang malah membuat dia kesusahan dalam belajar, akan berdampak buruk kepada hasil belajarnya. Maka dari itu, sebaiknya setiap mahasiswa tetap mengikuti kemampuan dalam dirinya sendiri dalam gaya belajarnya untuk memahami pembelajaran sehingga akan menumbuhkan hasil yang baik.

\section{SIMPULAN}

Dari uraian diatas, dapat disimpulkan bahwa setiap peserta didik memiliki karakteristik, kecerdasan, dan gaya belajar yang berbeda, oleh karena itu setiap individu memiliki kemampuan pemahaman dalam pembelajaran yang berbeda sesuai dengan gaya belajar yang dimilikinya, dan ini juga berpengaruh terhadap hasil belajarnya. Maka dari itu setiap pelaksana pendidikan harus bisa mengetahui dan memahami karakteristik dari setiap peserta didik agar pembelajaran dapat berjalan dengan lancar.

Organisasi memberikan dampak melalui beberapa faktor baik dari diri sendiri maupun dari luar, antara lain pola fikir dan pandangan yang semakin dewasa akibat pergaulan yang ditimbulkan oleh teman organisasi, cara membagi waktu antara kuliah dan organisasi, jiwa kompetensi dalam emraih prestasi, serta pengalaman organisasi yang dijadikan sebagai pembelajaran. Tetapi tidak semua individu menyukai organisasi, mereka yang tidak bisa membagi waktu nantinya akan tidak bisa fokus dalam pembelajaran dan berdampak pada hasil belajarnya. Oleh sebab itu, minat bakat setiap mahasiswa pasti berbeda-beda tergantung setiap individu itu sendiri menyikapinya.

\section{SARAN DAN UCAPAN TERIMA KASIH}

Selain mahasiswa, guru juga memiliki gaya mengajar yang berbeda-beda, sebaiknya setiap individu dan guru juga bisa sama-sama menyesuaikan dengan gaya mengajar, karena tidak semua guru cara mengajarnya sama dengan gaya belajar setiap mahasiswa. Selain itu mahasiswa juga bisa belajar dengan cara yang lain agar tidak tergantung terus pada gaya belajarnya itu dan membuatnya malas memperhatikan guru yang menurutnya gaya mengajarnya tidak sesuai dengan dirinya.

Program studi dan universitas diharapkan dapat membantu mahasiswa dalam menunjang kegiatan keorganisasian yaitu salah satunya dengan memberikan dukungan berupa motivasi yang berisi saran untuk mengikuti organisasi dan menyediakan sarana dan prasarana yang memadai, agar mahasiswa mampu mengembangkan bakat minat yang dimiliki serta menambah wawasan di bangku perkuliahan. Karena terlalu aktif dalam kegiatan organisasi mahasiswa kurang bisa membagi waktu kuliah dan kegiatan berorganisasi. Mahasiswa sebaiknya membagi setiap 
kegiatannya ke dalam skala prioritas sehingga dapat menjalankan setiap kegiatannya dengan baik dan terjadi keselarasan antara kuliah dengan kegiatan di luar perkuliahan.

Banyak pihak yang telah membantu dalam penulisan artikel ilmiah ini, penulis mengucapkan terima kasih terhadap pihak yang telah membantu demi kelancaran penulisan artikel ilmiah ini.

\section{DAFTAR PUSTAKA}

Cahyandaru,H. 2013. Pengaruh Keaktifan Siswa Dalam Ekstrakurikuler Terhadap Prestasi Belajar Siswa Kelas XI MAN Yogyakarta II. Fakultas Teknik Universitas Negeri Yogyakarta

Hadi, I. 2017. Pentingnya Pengenalan Tentang Perbedaan Individu Anak Dalam Efektivitas Pendidikan. Jurnal Inspirasi Vol.01 No.1

Hermawan, A. 2016. Mengetahui Karakteristik Peserta Didik Untuk Memaksimalkan Pembelajaran. Universitas Negeri Yogyakarta

Latubessy, A. 2015. Analisa dan Perancangan Model Keputusan Bakat dan Minat Anak. Jurnal SIMETRIS Vol.6 No.1

Pradayu, M. 2017. Pengaruh Aktivitas Organisasi Terhadap Prestasi Belajar. JOM FISIP Vol.04 No.2

Pratiwi, S. 2016. Pengaruh Keaktifan Mahasiswa Dalam Organisasi dan Motivasi Belajar Terhadap Prestasi Belajar Mahasiswa. Universitas Negeri Yogyakarta

Purwanto. 2004. Ilmu Pendidikan Teoritis dan Praktis. Bandung : Remaja Rosida Karya Saputro,A. 2016. Pengaruh Keaktifan Berorganisasi dan Prestasi Belajar Terhadap Kesiapan Kerja
Mahasiswa. Universitas Sebelas Maret Surakarta
Thiovva, E. 2014. Studi tentang Keaktifan Siswa Mengikuti Kegiatan Ekstrakurikuler. Sekolah Tinggi Keguruan dan Ilmu Pendidikan (STKIP) PGRI Sumatra Barat Padang 